\title{
Strategies to promote university permanence in times of COVID-19
}

\section{Estrategias para propiciar la permanencia universitaria en tiempos de la COVID-19}

\author{
KATT-MORALES, Luz Alondra $\dagger^{*}$, DOMINGUEZ-CAMPOMANES, Margarita, GOMEZ-MANUEL, \\ Esbeidy and MORALES-REYES, Eunice
}

Universidad Tecnológica del Sureste de Veracruz, Av. Universidad Tecnológica Lote grande, Número 1, sin colonia, Nanchital, Veracruz.

ID $1^{\text {st }}$ Author: Luz Alondra, Katt-Morales / ORC ID: 0000-0002-9982-8718, arXiv Author ID: 2417152, Researcher ID Thomson: S-6606-2018, CVU CONACYT ID: 412698

ID $1^{\text {st }}$ Co-author: Margarita, Domínguez-Campomanes / ORC ID: 0000-0003-0736-6112, arXiv Author ID: 2635670, Researcher ID Thomson: G-5015-2019, CVU CONACYT ID: 947280

ID $2^{\text {nd }}$ Co-author: Esbeidy, Gomez-Manuel / ORC ID: 0000-0003-0765-3402, arXiv Author ID: 2419916, CVU CONACYT ID: 599053

ID $3^{\text {rd }}$ Co-author: Eunice, Morales-Reyes / ORC ID: 0000-0003-0658-6957, Researcher ID Thomson: S-4739-2018, CVU CONACYT ID: 345179

DOI: $10.35429 / J U P .2021 .14 .5 .28 .36$

Received July 10, 2021; Accepted September 28, 2021

\begin{abstract}
The research provides strategies that allow to promote school permanence at the Technological University of the Southeast of Veracruz (TUSV) during the period of confinement derived from the contingency due to SARS COV II. Information was collected from various sources: department of school services, tutoring and through a survey-type instrument with seventy questions, using the Likert scale and it was carried out to evaluate four tutorial areas experienced during the pandemic, such as: health, academic, socioeconomic, and personal. The survey was applied to 420 students out of a population of 1208 , for which there is a level of confidence higher than $95 \%$. Derived from the analysis of data on failure, monitoring of tutorials and tutorial areas, the diagnosis was made, generating a list of findings, derived from the above, strategies validated by a group of experts are proposed, such as: Establish an induction program for teachers and students, institutionalization of leveling courses related to the result of the entrance exam, creating the area of emotional support, Implementing technological tools for academic monitoring, establishing regularization groups, peer support, positive incentives for outstanding students, generating financial plans and establish a personal development program.
\end{abstract}

Strategies, Permanence, Desertion

\begin{abstract}
Resumen
La investigación aporta estrategias que permitan propiciar la permanencia escolar en la Universidad Tecnológica del Sureste de Veracruz (TUSV) durante el periodo de confinamiento derivado de la contingencia por SARS COV II. Se recopiló información de diversas fuentes: departamento de servicios escolares, tutoría y a través de instrumento tipo encuesta con setenta preguntas, empleando la escala de Likert y se ejecutó para evaluar cuatro ámbitos tutoriales experimentados durante la pandemia, como son: salud, académico, socioeconómico y personal. La encuesta se aplicó a 420 estudiantes de una población de 1208 , por lo que se tiene un nivel de confianza superior al $95 \%$. Derivado del análisis de datos sobre reprobación, seguimiento de tutorías y ámbitos tutoriales, se efectuó el diagnóstico, generando una lista de hallazgos, con lo anterior se proponen estrategias validadas por un grupo de expertos, tales como: Establecer programa de inducción a docentes y alumnos, institucionalización de cursos de nivelación relacionados con el resultado de examen de ingreso, crear del área de apoyo emocional, Implementar herramientas tecnológicas para el monitoreo académico, establecer grupos de regularización, acompañamiento por pares, estímulos positivos a estudiantes destacados, generar de planes financieros e instaurar un programa de desarrollo personal.
\end{abstract}

Estrategias, Permanencia, Deserción

Citation: KATT-MORALES, Luz Alondra, DOMINGUEZ-CAMPOMANES, Margarita, GOMEZ-MANUEL, Esbeidy and MORALES-REYES, Eunice. Strategies to promote university permanence in times of COVID-19. Journal of University Policies. 2021. 5-14: 28-36

\footnotetext{
* Correspondence to Author (e-mail: luz.katt@utsv.edu.mx)

$\dagger$ Researcher contributing as first author.
} 


\section{Introduction}

In Mexico, one of the main objectives of the national educational development plan consists of "guaranteeing the right of the population in Mexico to an equitable, inclusive, intercultural and comprehensive education", for the foregoing; This work try to contribute to the priority objectives of the Education Sector Program 2020-2024. In this sense, it seeks to identify and propose support strategies that allow providing equal environments, identifying economic, social, academic, health and personal gaps to contribute to the student's permanence.

School dropout is usually frequent in higher education institutions and during the confinement period it has been increasing, according to what is mentioned in statista (Statista, 2021) it is estimated to be more than 2.83 million students. This work try to identify reasons for dropping out, for this, information is reported from 14 educational programs, with the participation of $63 \%$ of men and $37 \%$ of women, evaluating four tutorial areas: health, academic, socioeconomic and personal, those were experienced during the period of Virtual classes, in the same way, data on failure, dropout, subjects with higher dropouts are analyzed, tutorial follow-up, in order to identify areas of opportunity that allow the generation of strategies that promote university student permanence.

\section{Theoretical Framework}

The United Nations Educational, Scientific and Cultural Organization (UNESCO) is an institution trying to establish peace through international cooperation in education, science, and culture. UNESCO considers that "education is a fundamental human right for everyone, throughout life, and that access to education must be accompanied by the quality". (UNESCO, 2021) This right to education refers to all educational levels, so the university environment is no exception. In this, the role of tutoring has not had the importance that it requires, it is usually taken as one of the teacher's activities, or like an assignment of a few hours to a tutor, but as Garzón says (Garzón Daza, 2018, p.98) if "it seeks to offer a positive response, it does not achieve the desired results, because the teachers do not have the necessary knowledge to carry out the tutorial work".
Considering the May 2020 publication by the World Bank Group in the article called COVID-19: Shocks to education and policy responses, "the COVID-19 (coronavirus) pandemic represents a threat to the advancement of education in all over the world", due to the closures of the educational centers and the economic problems faced caused by the governance strategies implemented. Therefore, it is imperative to work together with the board to counteract the effects produced by the pandemic, where the closure of schools increased the dropout rate and therefore inequity.

In 2021, in the publication by the World Bank "Acting now the Human Capital of Our Children: The costs and response to the impact of the COVID-19 pandemic in the education sector of Latin America and the Caribbean", mentions the unparalleled challenge faced today, being "an exceptionally difficult situation, which opens a window of opportunities to rebuild educational systems, trying to make them more effective, equitable and resilient." Similarly, the efforts made by countries such as: Uruguay, Mexico, Brazil, and Chile; to establish models of distance education, with the purpose of mitigating the consequences of school closures, including the high rate of student dropout at all educational levels.

Mexico worked with a multimodal strategy, "Learn at home", resuming an educational program launched in 1968, to support distance education for about 25 million students, this strategy includes a special radio modality to reach indigenous communities during the confinement stage. (World Bank, 2021), at the same time they also worked with digital resources, which represented a greater challenge due to the limitation of internet access in disadvantaged households.

According to what was mentioned by Dr. Lorenza Villa Lever, in her conference at the effects of a pandemic seminar, held on November 25, 2020, for the higher level in Mexico, distance education evidenced technological inequality, as well as the lack of technological and pedagogical skills in teachers, which represents an adaptation challenge for students, especially for vulnerable groups. 
However, the application of strategies to contribute to the training of higher-level students were adapted by each educational institution, seeking appropriate platforms, providing guidance to teachers.

The application of strategies to promote permanence is essential in universities, so they must be implemented in an ideal way according to each situation, taking into account dropout, failure, areas of knowledge, tutorial environments (health, academic, socioeconomic and personal)

\section{Problematic}

The tutoring program is one of the fundamental components of student service, is recognized by the accrediting centers, the Council for the Accreditation of Higher Education (COPAES), since they point out that tutoring is essential to evaluate the educational quality by means of the attention and follow-up of students.

According to the National Association of Universities and Institutions of Higher Education (ANUIES), tutoring is defined as: A process of accompaniment during the training of students, which is specified through personalized attention to a student or a small group of students, by competent and trained academics for this role, conceptually relying on learning theories rather than teaching. Given the above concept, the TUSV has tutors, who are involved in the accompaniment process for the detection, orientation, channeling, monitoring, evaluation, and analysis of student situations, to provide timely attention and improve the services offered by the institution.

Tutoring is an accompaniment process whose objective is to guide the TUSV tutors in the academic environment to facilitate autonomy in their comprehensive training, however, to achieve this, the tutor must have the training that allows knowing the student's status or the ability to consign to the corresponding area.

Accompaniment at the upper secondary level should not be degraded, since the young person is in a process of intrapersonal growth, maturity, autonomy and decision making, so the tutor acts as a guide in the academic and university environment.
Throughout the 18 years, since the creation of TUSV, until the present time tutoring has been done, however, with this research project it is intended to show a pattern that allows identifying factors that affect academic performance, causing failure or school dropout. Is important to point out that some of the dropout factors are related to the vocational profile, which defines interests, aptitudes, personality and abilities that a person has with respect to the choice of the university career, other factors intervene such as economic, family, social and personal (Calvache, et al, 2018) so that, it is tried to generate suitable strategies in the university, relevant according to the current scenario caused by COVID-19.

The COVID-19 pandemic caused by the SARS COV II, new coronavirus is, without a doubt, the greatest transformation presented in the education sector worldwide. Most of the educational systems took as a health prevention measure, the closure of institutions, from the first case at the beginning of 2020, with this the arduous work was undertaken for the change of modality, being "an emergent adjustment due to the health context, where Information and Communication Technologies (ICT) were used to face the situation" as Miguel Román (Miguel, 2020, p14 mentioned)

\section{Methodology}

The object of this work can serve as a diagnosis, characterization, validation of its results through its indicators. Five processes were followed to carry it out: compilation, analysis, diagnosis, validation, and plan. The collection consists of the acquisition of data, this is done from three sources: school services, student services and an instrument applied to students. The analysis tries to identify the contribution of value in the data, regarding vulnerability and risk, with the diagnosis the parameterization is sought, to obtain a list of findings in the data collected. Validation is the work with expert personnel to refine findings and review strategies to select the appropriate ones. The plan is the result of the bibliographic and experience-based documentary strategies selected to promote student permanence from four angles: health, academic, socioeconomic, and personal at TUSV. 


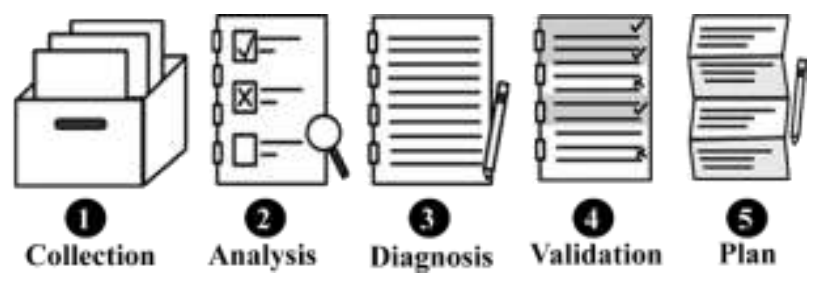

Graphic 1 Model to structure strategies that promote student permanence at TUSV

\section{Data Collection}

The population under study consists of 1208 students enrolled in the TUSV in the period May-August 2021. In accordance with the above, the population sample was determined by means of the equation "for studies whose main variable is quantitative" (Barojas, 2005):

$$
\mathrm{n}=\frac{\mathrm{N} \mathrm{Z} \mathrm{S}^{2}}{\mathrm{~d}^{2}(\mathrm{~N}-1)+\mathrm{Z}^{2} \mathrm{~S}^{2}}
$$

$\mathrm{N}=$ population size $=1208$ students

$\mathrm{d}=$ margin of error $(5 \%=0.05)$

$\mathrm{Z}=$ standard deviation according to the confidence level. $(95 \%=1.96)$

$\mathrm{S}^{2}=$ variance of the study population $(0.5)^{2}$

The instrument "Tutorial Areas" was executed in $34.6 \%$ of the student population, which corresponds to 420 students of the 292 required to obtain the $95 \%$ confidence level and with a margin of error of $5 \%$, the greater the number of applications it increases by confidence level and decreases the margin of error.

The design of the "Tutorial Areas" collection instrument has seventy questions, the Likert scale was used, which allowed getting information on: educational program, origin information, total number of people in the home, characteristics of their personal and economic situation, academic, social; health status, availability of technological tools among other variables, covering health, academic, socioeconomic, and personal areas.

Regarding the information on "monitoring of tutorials", it was compiled from April 26 to 30, aimed at students enrolled in the 14 educational programs: having a confidence level of $95 \%$. The applied instrument covers points such as: assistance, empathy, orientation, remission, follow-up, educational strategies, communication, resilience, and ethics.
On the other hand, academic data were obtained from 2018 to 2020, on: dropouts and reasons for withdrawal, for each educational program, number of students for each failed subject, high school of origin.

\section{Analysis of data}

The data collected from the survey carried out on the population sample is analyzed to determine the situation of the students during the period of confinement, identifying situations in the areas of health, academic, socioeconomic, and personal, tutorial situation, as well as failure rates, subjects with higher failure, failure frequency and origin of the students.

The analysis process of different variables is carried out, the comparative graphical method, parametric statistics is used to determine the highest frequency, the highest degree of acceptance or the situation most experienced, in this way to obtain parameters for the generation of permanence strategies.

\section{Diagnosis}

After the analysis, a series of situations were identified that allow generating a list of existing problems in the student population to turn them into strategies that allow to promote permanence. For the generation of the diagnosis, the identified opportunity areas were grouped according to the four tutorial areas: Health, academic, socioeconomic, and personal.

\section{Validation}

For the validation, it is suggested to work by consulting experts, "with the necessary assessment of no less than 30 subjects" (Añorga, et al, 2008, p.27), who identify themselves as expert personnel in the study area, where they issue its assessment regarding the strategies proposed, these strategies being bibliographic documentary and based on experience. For this, a group of experts with 6 teachers, 14 tutors, 3 external experts and 7 managers is used.

\section{Strategic plan}

After the review by the experts, the plan is written with the strategies identified that allow the permanence of the students, considering the focus of efforts and prioritization of actions. 


\section{Results}

With the application of the model described above, the following data were obtained during the confinement period:

On health, the following elements stand out:

$34.8 \%$ of the population have been a confirmed case of SARS COV II.

The emotions with the greatest presence in students are despair (12.28\%), sadness $(12.12 \%)$ and anguish $(8.86 \%)$

- $\quad$ The predominant feelings perceived in confinement are stress $(39.51 \%)$ and anxiety $(28.37 \%)$

- $\quad 10 \%$ of the population suffers from some type of disease such as: asthma, anemia, cancer, anxiety.

- $\quad 34.52 \%$ are overweight.

- Alcohol intake in young people increased by $2.84 \%$

\section{Situations Presented in confinement}
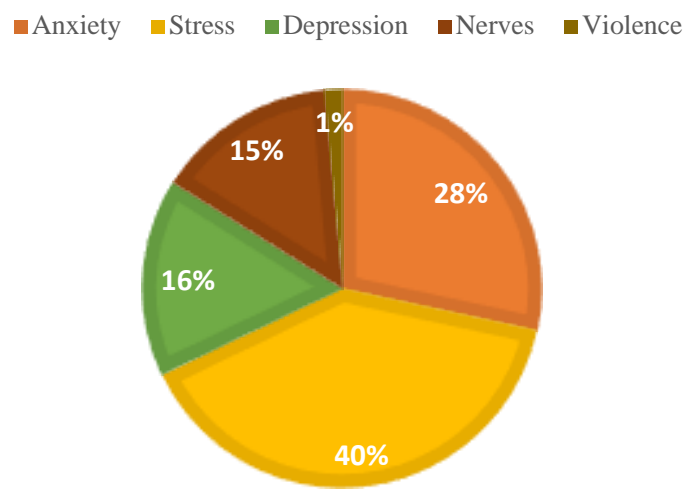

Graphic 2 Situations presented during the pandemic

\section{Academic filed}

- $\quad$ Majority origin from high school.

- $\quad$ Most of those enrolled come from public schools, however, the income of students from private institutions has been increasing.

- $\quad 28.9 \%$ of the students coincide in virtual classes with a family member.

- $\quad 60 \%$ share the virtual classroom space.

- $54.63 \%$ use the smartphone as an educational tool.

- Internet service is mentioned as the first factor of absence from school.

Lack of promotion of consultancies or regularization activities
- $\quad$ Students rarely or never report academic problems to tutors.

It is important to identify the main causes of desertion to approach them adequately, which is why the following data is presented:

- The September - December period is when there is the greatest number of withdrawals, with new students being the predominant ones.

- In 2018 there were 513 casualties, in 2019 it decreased to 354 and in 2020 only 346.

- $\quad$ From 2018 to 2020, dropouts due to failure are the main reason for dropping out.

- $\quad$ The dropout due to failure in 2018 was 343, 2019237 and 2020 of 258 students respectively.

- $\quad$ In 2018, the educational programs (EP) with the highest loss due to failure were: Higher University Technician in Industrial Maintenance (HUT IM), Higher University Technician in Mechatronics and Higher University Technician in Industrial Chemistry (HUT IC).

- In 2019, the EP's with the highest failure rates are: HUT IC, HUT IM, HUT Automotive Mechanics (HUT AM)

- In 2020 they are: HUT IC, HUT IM, HUT Mechatronic (MT), HUT Accounting (HUT C) those with the highest disapproval.

- $\quad$ The areas of knowledge with the highest frequency of failure are:

- Industrial Maintenance Engineering (IME), Mechatronics Engineering (ME), Chemical Process Engineering (CPE) was the Scientific Training and Information Technology Engineering (IEI) is the area of technological training.

- The areas of Technological Training represent the main cause of failure for HUT IM, HUT IT, management skills in HUT MT and HUT IC, Basic Sciences applied for the EP HUT in Accounting.

The subjects with the highest failure frequency by educational program are IME Mathematics for Engineers II (2018), Mathematics for Engineering (2019), Environmental Management (2020). 
HUT IM- Computing (2018), Sociocultural Training IV (2019), Sociocultural Training I (2020).

MTE- Mathematics for Engineering (2018), English VII (2019).

HUT MT- English II (2018), Oral and Written Expression (2019), Computer Tools (2020)

CIE - Mathematics for Engineering (2018), Mathematics for Engineers II (2019), English VII (2020).

HUT IC - Basic Chemistry (2018), Sociocultural Training (2019), Basic Chemistry (2020).

ITE - Integradora (2018), Administración del tiempo, redes LAN WAN (2020).

HUT IT - Database, programming, administration of the IT function (2018), English and sociocultural training III (2019), Programming (2020).

HUT Administration - Computing (2018 and 2019), Mathematics I (2020).

HUT C- Mathematics (2018), Computing and Mathematics (2019), Management Fundamentals and Mathematics (2020).

HUT AM - Computer Science (2018), English I (2019), Strength of Materials (2020)

- Among the reasons for dropout, the change of university and / or change of residence is the second cause.

- The third reason for dropout is the noncompletion of the registration process.

- The area of scientific training is the one with the highest dropout rate.

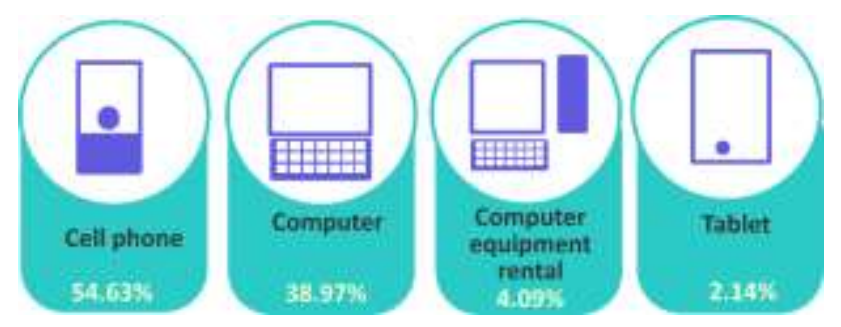

Graphic 3 Device used as an academic tool mostly used in virtual classes
Dropout from 2018-2020

- $2018=2019 \approx 2020$

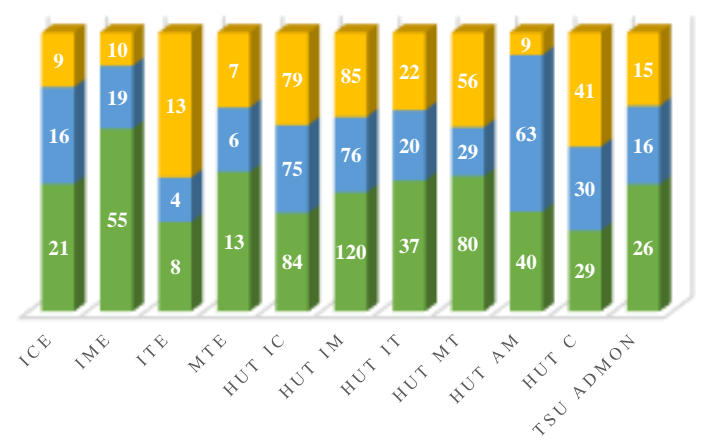

Graphic 4 Dropout from 2018-2020 by educational program

In the socioeconomic field

- $\quad$ The origin of the students is from the city of Coatzacoalcos and congregations.

- $\quad$ The origin of the students is usually from places with a low and very low degree of marginalization; however, the localities of their municipalities are classified as having a high or very high marginalization index.

- $\quad$ Economic and family health factors have affected student performance, this being a common factor in Latin American countries, such as Argentina, as described by Anaïs (Roing \& Blanco, 2021), where confinement, loss of jobs evidences the precariousness of life.

\begin{tabular}{|l|l|r|r|r|r|l|}
\hline \multicolumn{7}{|c|}{ Higher enrollment of students by location } \\
\hline Location & & $\mathbf{2 0 1 8}$ & $\mathbf{2 0 1 9}$ & $\mathbf{2 0 2 0}$ & Total & $\begin{array}{c}\text { Degree of } \\
\text { Margnalization }\end{array}$ \\
\hline Acayucan & Veracruz & 10 & 20 & 7 & 37 & Midium \\
\hline Agua Dulce & Veracruz & 63 & 68 & 85 & 216 & Very high \\
\hline R.cabada & Veracruz & 47 & 16 & & 63 & Midium \\
\hline Chinameca & Veracruz & 11 & 36 & 13 & 60 & Midium \\
\hline Coatzacoalcos & Veracruz & 884 & 791 & 563 & 2238 & Very low \\
\hline Allende & Veracruz & & 6 & 44 & 50 & Midium \\
\hline Cosoleacaque & Veracruz & 55 & 21 & 52 & 128 & Low \\
\hline Cuichapa & Veracruz & 1 & 2 & 32 & 35 & Midium \\
\hline Hidalgotitlán & Veracruz & 19 & 14 & 11 & 44 & High \\
\hline $\begin{array}{l}\text { Ixhuatlán del } \\
\text { Sureste }\end{array}$ & Veracruz & 180 & 80 & 163 & 423 & Midium \\
\hline Jáltipan & Veracruz & 39 & 8 & 20 & 67 & Midium \\
\hline Las Choapas & Veracruz & 37 & 15 & 13 & 65 & High \\
\hline Matías Romero & Oaxaca & 7 & 2 & 6 & 15 & Midium \\
\hline Minatitlán & Veracruz & 132 & 216 & 78 & 426 & Low \\
\hline Moloacan & Veracruz & 109 & 24 & 43 & 176 & Midium \\
\hline Nanchital & Veracruz & 565 & 536 & 369 & 1470 & Low \\
\hline Oteapan & Veracruz & 4 & 1 & 15 & 20 & Midium \\
\hline $\begin{array}{l}\text { Santa María } \\
\text { Jalapa Oaxaca }\end{array}$ & 2 & 2 & 16 & 20 & Midium \\
Marqués del & & & & & & \\
\hline Zaragoza & Veracruz & 9 & 9 & 6 & 24 & Very high \\
\hline
\end{tabular}

Table 1 Degree of marginalization by locality of enrolled students 
In the personal sphere:

- $\quad$ The decrease in school performance is associated with distractions at home.

- Support for family sustenance has been the main trigger for school dropout thinking, followed by the loss of a family member.

- $38.5 \%$ comment that they need emotional support.

The diagnostic information shows the main situations faced by the students of the TUSV during the period of confinement, so strategies are established that adapt to the current situation that promote the permanence of the students in the institution, these were classified according to with the four areas investigated, it should be mentioned that it does not eliminate the problems completely, it will be necessary to generate new strategies according to their evolution.

Consequently, from the diagnosis obtained, the group of experts validated strategies that provide possible solutions to the problems to promote the permanence of the students.

Strategies to promote university student permanence.

Health

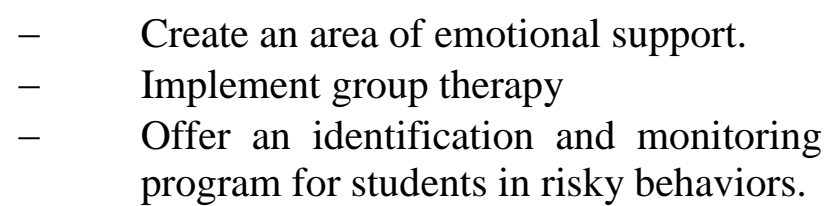

Academic

- Implement a technological tool for timely academic monitoring.

- $\quad$ Strengthen the tutorial action of peer support, as a means of regularization to mitigate the lag.

- Strengthen synchronous and asynchronous accompaniment.

- Update the tutorial process for the selection and evaluation of tutors.

- $\quad$ Tutor training program.

- Create regularization program through consultancies, led by full-time professors.

- Give positive encouragement to outstanding students.
- Implement learning strategies, identifying learning channels in students.

- Training teachers in the design of material according to the learning channels.

- $\quad$ Teacher training for the development of b-learning material.

- $\quad$ Create an induction program for teachers and students based on the educational model, evaluation process and institutional services.

- $\quad$ Strengthen the academic leveling course with topics that derive the diagnostic test to strengthen the basic areas of knowledge.

- Include in the quality management system the risk and / or vulnerability report by identified subject.

- $\quad$ Languages within the working group for each educational program.

\section{Socioeconomic}

- $\quad$ Continue with financing plan.

- To assign scholarships considering the degree of marginalization according to the origin of the student and priority areas of attention.

- Consider the scholarship to students who are part of peer regularization.

- Create economic incentives for participation in curricular activities.

- Strengthen the stimulus program that promotes academic excellence.

Personal

- Create a program to strengthen the capacities of the student in their human formation process. (Espinoza, et al. 2020)

\section{Acknowledgments}

This work has been supported by, Master Julio Cesar Sandria Reynoso, and PhD Araceli Torres Medina, so the autor wishes to thank them because they contribute to grown up the investigation. 


\section{Conclusion}

This document describes the support strategies because of a propositional methodology, with a bibliographic, quantitative descriptive documentary design and based on the experiences of tutors, validated by a group of experts. With investigation is intended to adopt the strategies within the educational institution.

The following conclusions were
produced.

1. The strategies to promote the permanence in the TUSV are oriented mainly to the academic field.

2. The inclusion of information technologies offers the availability of information and access at the time required for decision-making.

3. The regularization and peer support program offer an opportunity to students with lag problems to adjust their knowledge during the quarter.

4. Knowledge of the tutoring process will allow teachers and students to channel to the indicated areas and the use of the student services offered in the TUSV, in the same way, in the same way the accompaniment remains through synchronous and asynchronous activities.

5. The emotion management program will support young people who express the need for an intervention.

6. The purpose of financing plans is to support students targeted as vulnerable.

7. Establishing strategies by means of a group of experts allows obtaining results according to the current needs of the student.

8. By establishing support in the human formation process, it allows the integral formation of the student.

According to Torregiani and Alonso, the post-pandemic scenario is far from being resolved, not only is the incorporation of information technologies enough, but also the development and coordination of training processes with teachers (Torregiani Alonso, 2021).
Likewise, the coordinated work between the academic part, counseling, and student services are of vital importance for decisionmaking. (García et al, 2021). Understanding the causes of student dropout involves all the elements that intervene in the learning process, when young people dropout their studies, they abandon the possibilities of getting better opportunities, of cutting the stigma of income inequality and poverty. The social repercussions grow, since productivity and the rate of growth are diminished, as educational institutions must consider strategies that allow offering opportunities through far-reaching policies.

\section{References}

Actuemos ya para Proteger el Capital Humano de Nuestros Niños: Los Costos y la Respuesta ante el Impacto de la Pandemia de COVID-19 en el Sector Educativo de América Latina y el Caribe. (2021) World Bank, Washington, DC. World Bank. https://openknowledge.worldbank.org/handle/1 0986/35276

Aguilar Barojas Saraí. (2005). Fórmulas para el cálculo de la muestra en investigaciones de salud. Salud en Tabasco. ISSN: 1405-2091. VOL 11, núm, 1-2, pp 333-338

Añorga Morales, Julia; Valcárcel Izquierdo, Norberto; Che Soler Justo (2008) La parametrización en la investigación educativa. VARONA, núm. 47, pp. 25-32

Cantidad de estudiantes que abandonaron la escuela como resultado de la pandemia por COVID-19 en México de abril a agosto de 2020, por nivel educativo. 2021. 14/07/2021. https://es.statista.com/estadisticas/1196796/dese rcion-escolar-nivel-educativo-covid-mexico/

Calvache Fernández Leidy Carolina, Alvarez Vallejo Valentina, Triviño Arbeláez Jorge Ivan, Quiceno Restrepo, Claudia, Pulgarin Giraldo Robinson. (2018). Técnicas de Minerías de Datos para la identificación de patrones de deserción estudiantil como apoyo a las estrategias de SARA (Sistema de Acompañamiento para el Rendimiento Académico). Revista de la Universidad Tecnológica de Panamá. Congresos CLABES. https://revistas.utp.ac.pa/index.php/clabes/articl e/view/ 2021 
COVID-19: Impacto en la educación y respuestas de política pública. (2020) World Bank, Washington, DC. World Bank. https://pubdocs.worldbank.org/en/14377159075 6983343/Covid-19-Education-Summaryesp.pdf

Espinosa Castro, Jhon Franklin, Hernández Lalinde Juan, Mariño Castro Leydi Maritza. (2020) Estrategias de permanencia universitaria. https://doi.org/10.5281/zenodo.4065045

Garzón Daza Cecilia (2018) La gestión educativa en la educación superior de cara a la consejería estudiantil. Boletín REDIPE, ISSN-e 2256-1536, Vol. 7, No. 8

García, C. S., Monge, J. R., Rizo, T. C., Fernández, M. J., Jiménez, M. I. S., Agüero, S. S., ... \& Chinchilla, A. L. (2021). Asegurar la permanencia estudiantil en la Universidad de Costa Rica durante la crisis sanitaria. Reflexiones desde la Vicerrectoría de Vida Estudiantil. Actualidades Investigativas en Educación, 21(3), 1-21.

Miguel Román José Antonio. (2020). La educación Superior en tiempo de pandemia: una visión desde dentro del proceso formativo. Revista latinoamericana de estudio educativos (México), vol. L, núm. Esp.-, pp. 13-40, 2020

La educación transforma vidas. 25/06/2021. https://es.unesco.org/themes/derecho-aeducacion

Programa sectorial derivado del plan nacional de desarrollo 2019-2024. México. 10/07/2021. http://www.dof.gob.mx/nota_detalle.php?codig $\mathrm{o}=5596202 \&$ fecha $=06 / 07 / 2020$

Roig, A., \& Blanco Esmoris, M. F. (2021). Producir lazo, organizar "la olla" y "contener" a otros/as. Experiencias de cuidado sociocomunitario durante la pandemia de la covid-19 en el AMBA (Argentina). Antípoda. Revista de Antropología y Arqueología, 29-51.

Torregiani F., Alonso, E. (2021). Experiencia de virtualización de cátedras en FACSO UNICEN: Decisiones, reflexiones y desafíos en pandemia por COVID-19. 